\title{
Effect of Preoperative Rinsing with $0.2 \%$ Chlorhexidine Digluconate on the Bacteremia Following Open Dental Extraction
}

\author{
Galina Gavazova1, Eli Hristozova ${ }^{2}$, StanimirKisselov ${ }^{1}$, Ralitsa Raycheva ${ }^{3}$, Nikolai Pavlov ${ }^{4}$, Petia \\ Pechalova $^{1 *}$ \\ ${ }^{l}$ Department of Oral surgery, Faculty of Dental medicine, Medical university - Plovdiv \\ ${ }^{2}$ Department of Microbiology and Immunology, Faculty of Pharmacology, Medical university - Plovdiv \\ ${ }^{3}$ Department of Social medicine and community health, Faculty of community health, Medical university - \\ Plovdiv \\ ${ }^{4}$ Private practice of Oral surgery, Plovdiv, Bulgaria
}

*Corresponding Author: Petia Pechalova, Department of oral surgery, Faculty of dental medicine, Medical University of Plovdiv, Bulgaria, Email: pechalova@abv.bg

Abstract: The bacteremia following open dental extraction has been studied by a number of authors.

Aim: The present study is to investigate the effect of preoperative rinsing with $0.2 \%$ chlorhexidine digluconate on the bacteremia following open extraction of tooth.

Materials and Methods: This research focused on evidence of bacteremia among 58 individuals, divided equally in two study groups - without preoperative rinsing (first group) and with preoperative rinsing (second group) with Parodontax Extra (GlaxoSmithKline, Great Britain), followed by closed extraction. Aerobic and anaerobic hem cultures (Bact/ALERT, BioMerieux, Inc., Durham, N.C.) were used to establish the bacteremia, while blood samples were obtained preoperatively, 30 seconds after and 15 minutes after the extraction was completed. All subjects were initially clinically evaluated in correspondence with Oral Health Assessment Tool (OHAT) for dental screening.

Results: Preoperative bacteremia was established in 2 (3.4\%) patients - one from each study group. At the $30^{\text {th }}$ second after the extraction was done bacteremia was established in $3(5.2 \%)$ patients from the first and in $2(3.4 \%)$ patients from the second group. At the $15^{\text {th }}$ minute mark bacteremia was found in one (1.7\%) patient from the first group. We failed to identify any statistically significant difference between the occurrence of bacteremia among subjects from both groups 30 seconds ( $p=0.647)$, as well as 15 minutes $(p=0.322)$ after the extraction was completed. The initial preoperative condition of the oral cavity cannot be considered as a factor that may influence the postoperative bacteremia 30 seconds after extraction $(p=0.219)$, however it affects the preoperative $(p=0.001)$ and postoperative bacteremia 15 minutes after extraction $(p<0.0001)$.

Conclusions: Preoperative rinsing with $0.2 \%$ chlorhexidine digluconate does not appear to offer any statistically significant reduction of the occurrence of postextraction bacteremia following open dental extraction.

\section{INTRODUCTION}

Tooth extraction causes transitory bacteremia, which was first described by Okell and Elliott in 1935. [1] Historically, several different authors have been pursuing the subject of bacteremia following open extraction. [2-4] Chlorhexidine mouthwashes have a pronounced antimicrobial effect on salivary microflora [5,6] and supragingival plaque [7], as suggested by evidences in the literature. Therefore, the notion exists, that such mouthwashes can be used prior to oral surgical procedures in order to reduce the number of bacteria in the mouth, and hence the number of bacteria, which enter the circulation. However, scientific evidences on the effect of chlorhexidine - the most thoroughly studied antiseptic for prevention of bacteremia after dental procedures - are conflicting. [8-10] Aim of the present study is to investigate the effect of preoperative rinsing with $0.2 \%$ chlorhexidine digluconate on the bacteremia following open extraction of tooth.

Materials and methods: 58 subjects of the study were equally divided in two study groups - first 
group did not rinse with $0.2 \%$ chlorhexidine digluconate preoperatively and the second group did. Inclusion criteria were (1) clinically healthy patient; (2) open extraction of a single tooth was necessary. Exclusion criteria were: lack of consent, multiple extraction, pharmaceutically controlled chronic conditions, use of antibiotics in the last 6 months, acute oral inflammation, tumors and malignancies, compromised immune system, diabetes mellitus, pregnancy, history of/upcoming radiotherapy to the head and neck region. All patients received initial preoperative clinical examination according to Oral Health Assessment Tool (OHAT) for dental screening (a modification to the Kayser-Jones [11] scale and Chalmers andPearson [12] scale (table 1). General clinical status is represented by the aggregate of all represented variables.

Table1: Oral Health Assessment Tool

\begin{tabular}{|c|c|c|c|}
\hline Category & Healthy(0) & Altered(1) & Pathologic(2) \\
\hline Lips & Soft, pink, moist & $\begin{array}{l}\text { Dryand cracked } \\
\text { erythematous comisures }\end{array}$ & $\begin{array}{l}\text { Swelling and lumps, white and red } \\
\text { eroded plaques, bleeding or erosions in } \\
\text { the comisures }\end{array}$ \\
\hline Tongue & Normal, wet, pink & Fissurated, red, thrushed & Red or white erosion, swelling \\
\hline $\begin{array}{l}\text { Gingiva and } \\
\text { soft tissues }\end{array}$ & $\begin{array}{lr}\text { Pink, } & \text { mois } \\
\text { smooth, } & \mathrm{n} \\
\text { bleeding } & \end{array}$ & $\begin{array}{l}\text { Dry, shiny, rough, red, swollen } \\
\text { o around } 1 \text { to } 6 \text { teeth, single ulcer or } \\
\text { decubital erosion under the } \\
\text { denture }\end{array}$ & $\begin{array}{l}\text { Swollen, bleeding around } 7 \text { or more } \\
\text { teeth, loss of teeth, erosions and/or } \\
\text { ethite lesions, generalized redness, } \\
\text { tenderness }\end{array}$ \\
\hline Saliva & $\begin{array}{l}\text { Wet oral surface } \\
\text { thin and fre } \\
\text { flowing saliva }\end{array}$ & $\begin{array}{l}\text { Dry, stringy oral surfaces, reduces } \\
\text { amount of saliva, reported } \\
\text { xerostomia }\end{array}$ & $\begin{array}{l}\text { sry and erythematous structures, little } \\
\text { d or no saliva, thick, stringy saliva, } \\
\text { reported xerostomia }\end{array}$ \\
\hline Natural teeth & $\begin{array}{l}\text { No destroyed } \\
\text { fractured teeth }\end{array}$ & r1-3 damaged or fractured teeth & $\begin{array}{l}4 \text { or more damaged or fractured teeth, } \\
\text { abraded or more than } 4 \text { unrestored teeth }\end{array}$ \\
\hline Dentures & $\begin{array}{ll}\text { Regularly } & \text { use } \\
\text { dentures in goo } \\
\text { condition }\end{array}$ & $\begin{array}{l}\text { d Single damaged region or tooth of } \\
\mathrm{d} \text { the denture, used for } 1-2 \text { hours a } \\
\text { day }\end{array}$ & $\begin{array}{l}\text { More than one damaged region or tooth } \\
\text { alof the denture, poor adhesion prevents } \\
\text { use, or used only with adhesive }\end{array}$ \\
\hline Oral hygiene & $\begin{array}{l}\text { Clean surfaces } \\
\text { teeth and denture } \\
\text { no food debris } \\
\text { calculus }\end{array}$ & $\begin{array}{l}\text { Presence of food debris, plaque or } \\
\text { calculus in } 1 \text { or } 2 \text { regions of the } \\
\text { mouth, or on limited places on the } \\
\text { dentures, halitosis }\end{array}$ & $\begin{array}{l}\text { Presence of food debris, plaque and } \\
\text { ealculus in most of the mouth, or } \\
\text { egenerally on the dentures, severe } \\
\text { halitosis }\end{array}$ \\
\hline Dental pain & $\begin{array}{l}\text { No behaviora } \\
\text { verbal or physic } \\
\text { signs of pain }\end{array}$ & $\begin{array}{l}\text { 1, Verbal and physical signs of pain } \\
\text { such as grinning, lip biting, } \\
\text { aggression and refusal to eat }\end{array}$ & $\begin{array}{l}\text { Physical signs of pain - swelling on the } \\
\text { lheeks and gingiva, fractured teeth, } \\
\text { ulcers, abscess, verbal and behavioral } \\
\text { signs of pain }\end{array}$ \\
\hline Iggr & $\mathbf{0}$ & $1-8$ & $9-16$ \\
\hline
\end{tabular}

Immediately before surgery subjects in the second group rinsed their mouth two times with $10 \mathrm{ml} \quad 0.2 \% \quad$ chlorhexidine digluconate (Parodontax Extra, GlaxoSmithKline, Great Britain) for one minute each. The solution was given in two single-use chemically clean plastic cups. Patients did not rinse with water after that. Open tooth extraction was carried out in the following order: (1) field block or nerve block anesthesia; (2) traditional preparation and elevation of muco-periosteal flap; (3) uncovering the tooth; (4) removal of bone with surgical burr under water cooling, sectioning of the tooth if necessary; (5) extraction; (6) debridement and irrigation of the extraction site; (7) reflecting the flap to the original place and applying single sutures; (8) insertion of rubber drainage.

Several aerobic and anaerobic hemocultures, incubated in an automated system, were utilized for research of bacteriemia (Bact/ALERT, BioMerieux, Inc., Durham, N.C.). The site of venipuncture was disinfected with ethanol, followed by iodine solution. $5 \mathrm{ml}$ of venous blood for each hemoculture (aerobic and anaerobic) was collected from the cubital vein. Then another sterile needle was used to aseptically transfer the material from the syringe into the container which was timely brought to the microbiology laboratory.Three samples of paired hemocultures for aerobic and anaerobic bacteria were acquired accordingly: (1) preoperatively, prior to any manipulations in the mouth; (2) 30 seconds after the extraction was completed; (3) 15 minutes after the extraction was completed. The hemocultures were incubated in BactALERT 3D 60 (BioMerieux, Inc., Durham, N.C.) for 6 days. Positive hemocultures were transferred in solid and liquid nutrient mediums and prepared by Gram stain. Identification of the isolated strains was conducted according to the standard methods9 or automatically - using Vitek 2 (BioMerieux, 
Inc., Durham, N.C.). Some positive hemocultures that showed no bacteria through Gram staining were automatically subcultuvated up to 6 days and were deemed false-positive if no bacterial growth was evident. Hemocultures that were not marked by the device were subjected to routine incubation and transferred to solid nutrient mediums. Evident growth marked them as false-negative, whereas true-negative hemocultures showed no growth whatsoever. This study received funding in Project №HO-09/ 2018 of Medical university of Plovdiv.

\section{RESUltS}

40 out of all participants in the trial were females, and 18 were males. Female/male ratio in the first group was 2.63:1 and in the second it was 1.9:1. Average age of the patients in the first group was 26.24 (standard deviation of 1.65 ) and in the second it was 26.34 (standard deviation of 1.82). We did not establish any statistically significant relation between the age of both groups ( $\mathrm{p}=0.967) .56$ of the extracted 58 single teeth were mandibular third molars. Preoperative bacteremia was confirmed in 2 Table2. Isolated microorganisms after incubating the hemocultures.

\begin{tabular}{|c|c|c|c|c|c|c|}
\hline & \multicolumn{3}{|c|}{ First group } & \multicolumn{3}{|c|}{ Second group } \\
\hline & $\mathrm{n}$ & $\begin{array}{l}\text { Isolated from } \\
\text { aerobic } \\
\text { hemoculture }\end{array}$ & $\begin{array}{l}\text { Isolated } \\
\text { anaerobic } \\
\text { hemoculture }\end{array}$ & $\mathrm{n}$ & $\begin{array}{l}\text { Isolated from } \\
\text { aerobic } \\
\text { hemoculture }\end{array}$ & $\begin{array}{l}\text { Isolated from } \\
\text { anaerobic hemoculture }\end{array}$ \\
\hline $\begin{array}{l}\text { Preoperative } \\
\text { ly }\end{array}$ & 1 & $\begin{array}{l}\text { Staphylococc } \\
\text { usepidermidis }\end{array}$ & - & 1 & $\begin{array}{l}\text { Coagulase } \\
\text { negative } \\
\text { Staphylococcus } \\
\end{array}$ & - \\
\hline $\begin{array}{l}\text { At } \quad 30^{\text {th }} \\
\text { second mark }\end{array}$ & 3 & $\begin{array}{l}\text { Streptococcus } \\
\text { viridans; }\end{array}$ & $\begin{array}{l}\text { Streptococcus } \\
\text { viridans; } \\
\text { Actinomycesviscosus }\end{array}$ & 2 & $\begin{array}{l}\text { Coagulase } \\
\text { negative } \\
\text { Staphylococcus; }\end{array}$ & $\begin{array}{l}\text { Coagulase negative } \\
\text { Staphylococcus; } \\
\text { Streptococcus viridans; }\end{array}$ \\
\hline $\begin{array}{l}\text { At } \quad 15^{\text {th }} \\
\text { minute mark }\end{array}$ & 1 & $\begin{array}{l}\text { Actinomyces } \\
\text { viscosus }\end{array}$ & - & - & - & - \\
\hline
\end{tabular}

We studied the relation between preoperative condition of the mouth and the occurrence of bacteremia. Our findings revealed that higher values in the initial screening of the oral status correspond to higher probability of bacteremia preoperatively $(\mathrm{p}=0.001)$ and 15 minutes after the extraction $(p<0.0001)$. However, preoperative oral status is not a factor that can affect the bacteremia at the $30^{\text {th }}$ second after the extraction $(\mathrm{p}=0.219)$.

More specifically, the preoperative status of the gingiva demonstrated its relation to preoperative bacteremia $(\mathrm{p}=0.001)$ and post extraction bacteremia at $15^{\text {th }}$ minute mark $(\mathrm{p}<0.0001)$, but did not affect the bacteremia at the $30^{\text {th }}$ second mark $(\mathrm{p}=0.105)$. Further analysis determined that the level of oral hygiene does not appear to influence the occurrence of bacteremia
(3.4\%) patients - one in each group. At the $30^{\text {th }}$ second after extraction bacteremia was found in $3(5.2 \%)$ subjects from the first group and in 2 (3.4\%) from the second one.

Samples at the $15^{\text {th }}$ minute after the extraction revealed a single case of bacteremia $(1.7 \%)$ in the first group. We failed to recognize any statistically significant difference in occurrence of bacteremia between subjects in both groups at $30^{\text {th }}$ second mark $(\mathrm{p}=0.647)$, as well as at $15^{\text {th }}$ minute mark $(\mathrm{p}=0.322)$ after the extraction was completed. Most common findings in patients from the first group were Streptococcus viridians and Actinomycesviscosus (33.33\% of the positive aerobic and $50 \%$ of the positive anaerobic hemocultures). We also established that Coagulase negative Staphylococcus was present in all three positive hemocultures from the second group. Its facultative anaerobic nature allows it to benefit from both respiration and fermentative metabolism, which is why it may be found in both aerobic and anaerobic hemocultures. Register of the cultivated bacteria is presented in table 2 . preoperatively $(\mathrm{p}=0.017)$, as well as postoperatively - at the $30^{\text {th }}$ second mark $(\mathrm{p}=0.075)$, at $15^{\text {th }}$ minute mark $(\mathrm{p}=0.147)$.

\section{Discussion}

Our findings suggest that preoperative rinsing with $0.2 \%$ chlorhexidine digluconate does not affect the bacteremia following open extraction of teeth. Similar results are published number of other authors. Tuna et al. [9] compared the bacteremia following extraction of impacted third molars in patients who rinsed preoperatively with $0.2 \%$ chlorhexidine digluconate or saline. The reported occurrence of bacteremia in both groups was 33\% and 50\% respectively, which cannot be considered as statistically significant difference. Similar results are also published by Lockhart [14], who stated that preoperative rinsing with $0.2 \%$ 
chlorhexidine digluconate did not substantially reduce the occurrence of bacteremia, evident at $1^{\text {st }}$ and $3^{\text {rd }}$ minute after single tooth extraction. Duvall et al. [10] compared the effect of preoperative rinsing with $0.12 \%$ chlorhexidine, antibiotic and placebo on bacteremia after removal of third molars and reported no statistically significant difference between the study groups. In contrast, Tomas et al. ${ }^{15}$ showed that preoperative rinsing with $0.2 \%$ chlorhexidine dramatically reduced the occurrence of bacteremia at the $30^{\text {th }}$ second mark after multiple extraction. Managuttiet al. ${ }^{16}$ studied the effect of $0.2 \%$ chlorhexidine rinse on bacteremia following removal of third mandibular molar in 10 subjects in comparison with sterile water and 5\% povidone iodine. They reported bacteremia in $40 \%$ of the patients who used chlorhexidine, $20 \%$ of the patients who rinsed with povidone iodine and $60 \%$ of the control subjects.

\section{Conclusion}

Preoperative rinsing with $0.2 \%$ chlorhexidine digluconate does not appear to offer any statistically significant reduction of the occurrence of postextraction bacteremia following open dental extraction.

\section{REFERENCES}

[1] Okell CC and Elliott SD. Bacteremia and oral sepsis withspecial reference to the aetiology of subacute endocarditis. Lancet 1935; 2: 869-872

[2] Josefsson K, Heimdahl A, von Konow L, Nord CE. Effect of phenoxymethylpenicillin and Erythromycinprophylaxis on anaerobic bacteraemia after oral surgery. J Antimicrob Chemother 1985; 16:243-251.

[3] Okabe K, Nakagawa K, Yamamoto E. Factorsa ffecting the occurrence of bacteremia associated with toothextraction. Int J Oral Maxillofac Surg 1995; 24: 239-242.

[4] Rajasuo A, Perkki K, Nyfors S, JousimiesSomer H, MeurmanJH. Bacteremia following surgical dental extractionwith an emphasis on anaerobic strains. J Dent Res 2004; 83: 170- 174.

[5] Dahlén G. Effect of antimicrobial mouthrinses on salivary microflora in healthy subjects. Scand J Dent Res. 1984; 92(1):38-42.
[6] Jenkins S, Addy M, Newcombe RG. A comparison of cetylpyridinium chloride, triclosan and chlorhexidine mouthrinse formulations for effects on plaque regrowth. $\mathrm{J}$ Clin Periodontol. 1994; 21(6):441-4.

[7] Netuschil L, Weiger R, Preisler R, Brecx M. Plaque bacteria counts and vitality during chlorhexidine, meridol and listerine mouthrinses. Eur J Oral Sci.1995; 103(6): 355-61.

[8] Arteagoitia I, Rodriguez Andre's C, Ramos E. Does chlorhexidine reduce bacteremia following tooth extraction? A systematic review and metaanalysis. PLoS ONE 2018; 13(4): e0195592.

[9] Tuna A, Delilbasi C, Arslan A, Gurol Y, Tazegun Tekkanat Z. Do antibacterial mouthrinses affect bacteremia in third molar surgery? A pilot study. Aust Dent J. 2012; 57(4):435-9.

[10] Duvall NB, Fisher TD, Hensley D, Hancock RH, Vandewalle KS. The comparative efficacy of $0.12 \%$ chlorhexidine and amoxicillin to reduce the incidence and magnitude of bacteremia during third molar extractions: a prospective, blind, randomized clinical trial. Oral Surg Oral Med Oral Pathol Oral Radiol. 2013; 115(6):752-63.

[11] Kayser-Jones J, Bird WF, Paul SM, Long L, Schell ES. An instrument to assess the oral health status of nursing home residents. Gerontologist. 1995;35(6):814-24.

[12] Chalmers J, Pearson A. Oral hygiene care for residents with dementia: a literature review. J Adv Nurs. 2005;52(4):410-9.

[13] Murray PR, Baron EJ, Pfaller MA, Tenover FC, Yolken RH (ed.). 1995. Manual of clinical microbiology, 6th ed. ASM Press, Washington, D.C.

[14] Lockhart PB, Brennan MT, Sasser HC, Fox PC, Paster BJ, Bahrani-Mougeot FK. Bacteremia associated with toothbrushing and dental extraction. Circulation. 2008;117(24): 3118-25.

[15] Tomas I, Alvarez M, Limeres J, et al. Effect of a chlorhexidine mouthwash on the risk of postextraction bacteremia. Infect Control Hosp Epidemiol. 2007;28:577-582.

[16] Managutti A, Managutti SA, Patel J, Puthanakar NY. Evaluation of Post-surgical Bacteremia with Use of Povidone-Iodine and Chlorhexidine During Mandibular Third Molar Surgery. J Maxillofac Oral Surg. 2017;16(4):485-490.

Citation: Petia Pechalova, et. al, Effect of Preoperative Rinsing with $0.2 \%$ Chlorhexidine Digluconate on the Bacteremia Following Open Dental Extraction. ARCJournal of Dental science. 2019; 4(4):14-17. doi:dx. doi.org/10.20431/2456-0030.0404003.

Copyright: $\odot 2019$ Authors. This is an open-access article distributed under the terms of the Creative Commons Attribution License, which permits unrestricted use, distribution, and reproduction in any medium, provided the original author and source are credited. 